\title{
Crystal structure of the novel compound $\mathrm{Ce}_{3} \mathrm{Pt}_{4} \mathrm{Al}_{6}$
}

\author{
A.I. TURSINA ${ }^{1}$, A.V. GRIBANOV ${ }^{1}$, N.G. BUKHAN'KO ${ }^{1}$, P. ROGL ${ }^{2}$, Y.D. SEROPEGIN ${ }^{1}$ \\ ${ }^{1}$ Department of Chemistry, Moscow State University, Leninskie Gory, 119992 GSP-2 Moscow, Russia \\ ${ }^{2}$ Institut für Physikalische Chemie der Universität Wien, Währingerstraße 42, A-1090 Wien, Austria \\ * Corresponding author. Fax: +7 495 9390171; e-mail: tursina@newmail.ru
}

Received January 24, 2008; accepted February 17, 2008; available on-line March 31, 2008

The structure of the novel ternary aluminide $\mathrm{Ce}_{3} \mathrm{Pt}_{4} \mathrm{Al}_{6}$ was refined from $\mathrm{X}$-ray single crystal data in the orthorhombic space group Pnma with $a=13.6589(2), b=4.3331(1), c=17.4740(3) \AA, Z=4 ; R=0.049$. The structure can be described as built up from platinum centered trigonal prisms formed by cerium and aluminum atoms. These prisms form infinite columns in the [010] direction by sharing triangular faces. The columns are condensed into groups by edge sharing of the constituent trigonal prisms.

Cerium platinum aluminide / X-ray crystal structure determination / $\mathrm{Ce}_{3} \mathbf{P t}_{4} \mathbf{A l}_{6}$

\section{Introduction}

In previous papers we have reported on the crystal structures of the new compounds $\mathrm{CePt}_{3} \mathrm{Al}_{5}$, which belongs to the site exchange $\mathrm{YNi}_{5} \mathrm{Si}_{3}$ structure type [1], $\mathrm{Ce}_{0.67} \mathrm{Pt}_{2} \mathrm{Al}_{5}$ with $\mathrm{Gd}_{0.67} \mathrm{Pt}_{2} \mathrm{Al}_{5}$ type- and $\mathrm{Ce}_{1.33} \mathrm{Pt}_{3} \mathrm{Al}_{8}$ with $\mathrm{Gd}_{1.33} \mathrm{Pt}_{3} \mathrm{Al}_{8}$-type structure [2]. Further studies of the Ce-Pt-Al ternary system revealed the existence of one more new compound, $\mathrm{Ce}_{3} \mathrm{Pt}_{4} \mathrm{Al}_{6}$.

Up to now, only two structures with the general formula $\mathrm{RE}_{3} \mathrm{~T}_{4} \mathrm{M}_{6}(\mathrm{RE}$ - rare earth, $\mathrm{T}$ - transition element, $\mathrm{M}$ - p-element) are known from the literature: $\mathrm{Ce}_{3} \mathrm{Pt}_{4} \mathrm{Ge}_{6}$ [3], crystallizing in the space group Cmcm, $a=4.419(1), \quad b=26.222(5)$, $c=4.422(1) \AA$ and its monoclinically deformed variant $\mathrm{Y}_{3} \mathrm{Pt}_{4} \mathrm{Ge}_{6}$ [4], crystallizing in the space group $P 2_{1} / m, a=8.692(3), b=4.3062(8), c=13.162(3) \AA$, $\beta=99.45(4)^{\circ}$.

\section{Experimental details}

A sample with the nominal composition $\mathrm{Ce}_{33} \mathrm{Pt}_{22} \mathrm{Al}_{45}$ was arc-melted under high-purity argon from the elements (Ce 99.85, Pt 99.99, Al 99.99 wt.\%). Mass loss was less than $1 \mathrm{wt} \%$. The sample was annealed in an evacuated quartz tube at $550^{\circ} \mathrm{C}$ for one month, then quenched in cold water. A single crystal with the dimensions $\quad 0.05 \mathrm{~mm} \times 0.05 \mathrm{~mm} \times 0.045 \mathrm{~mm}$ was extracted from the surface of the alloy.

X-ray diffraction was carried out with a Nonius Kappa CCD diffractometer using graphitemonochromatized MoK $\alpha$ radiation. Most of the atoms were located by direct methods employing the program SHELXS-97 [5]. The structure was refined by SHELXL-97 [5]. Crystallographic details are summarized in Table 1. Atomic coordinates and equivalent atomic displacement parameters, with their standard deviations are given in Table 2. Selected interatomic distances are provided in Table 3.

Table 1 Data collection and structure refinement parameters for $\mathrm{Ce}_{3} \mathrm{Pt}_{4} \mathrm{Al}_{6}$.

\begin{tabular}{c|c}
\hline Space group & Pnma \\
Lattice parameters & $a=13.6589(2) \AA$ \\
& $b=4.3331(1) \AA$ \\
& $c=17.4740(3) \AA$ \\
Cell volume $\left(\AA^{3}\right)$ & $1034.21(3)$ \\
Formula per unit cell & 4 \\
Calculated density $\left(\mathrm{g} / \mathrm{cm}^{3}\right)$ & 8.751 \\
Scan range $($ degrees $)$ & $2.33 \leq \theta \leq 31.00$ \\
Linear absorption coefficient & 67.249 \\
(mm $\left.{ }^{-1}\right)$ & $-19 \leq h \leq 19$ \\
Range in $h k l$ & $-6 \leq k \leq 6$ \\
& $-24 \leq l \leq 25$ \\
Symmetry-independent & 1845 \\
reflections & 1793 \\
Reflections with $\mathrm{I}>2 \sigma(\mathrm{I})$ & 80 \\
Number of refined & 1.114 \\
parameters & 0.049 \\
Goodness of fit & 0.149 \\
$\mathrm{R}$ & \\
$\mathrm{R}_{\mathrm{w}}$ &
\end{tabular}


Table 2 Atomic coordinates and equivalent isotropic displacement parameters of $\mathrm{Ce}_{3} \mathrm{Pt}_{4} \mathrm{Al}_{6}{ }^{\mathrm{a}}$.

\begin{tabular}{l|l|l|l|l|l}
\hline Atom & Wyckoff site & $x$ & $y$ & $z$ & $\mathrm{U}_{\mathrm{eq}}\left(\AA^{2}\right)$ \\
\hline Ce1 & $4 c$ & $0.07521(7)$ & $1 / 4$ & $0.84864(5)$ & $0.0085(2)$ \\
Ce2 & $4 c$ & $0.30248(7)$ & $1 / 4$ & $0.03267(5)$ & $0.0080(2)$ \\
Ce3 & $4 c$ & $0.36757(7)$ & $1 / 4$ & $0.80618(5)$ & $0.0083(2)$ \\
Pt1 & $4 c$ & $0.07161(5)$ & $1 / 4$ & $0.42837(4)$ & $0.0079(2)$ \\
Pt2 & $4 c$ & $0.08973(5)$ & $1 / 4$ & $0.18707(4)$ & $0.0112(2)$ \\
Pt3 & $4 c$ & $0.14853(4)$ & $1 / 4$ & $0.67761(4)$ & $0.0075(2)$ \\
Pt4 & $4 c$ & $0.37790(4)$ & $1 / 4$ & $0.49254(4)$ & $0.0086(2)$ \\
Al1 & $4 c$ & $0.0265(4)$ & $1 / 4$ & $0.5669(3)$ & $0.0082(9)$ \\
Al2 & $4 c$ & $0.0562(4)$ & $1 / 4$ & $0.0437(3)$ & $0.0097(9)$ \\
Al3 & $4 c$ & $0.2507(4)$ & $1 / 4$ & $0.3963(4)$ & $0.0123(10)$ \\
A14 & $4 c$ & $0.2721(4)$ & $1 / 4$ & $0.2281(3)$ & $0.0082(9)$ \\
Al5 & $4 c$ & $0.3277(4)$ & $1 / 4$ & $0.6306(3)$ & $0.0077(9)$ \\
Al6 & $4 c$ & $0.4605(4)$ & $1 / 4$ & $0.1915(3)$ & $0.0085(9)$ \\
\hline
\end{tabular}

${ }^{\mathrm{a}}$ The structure was refined with anisotropic displacement parameters for all atoms. The positional parameters were standardized using the program STRUCTURE TIDY [6].

\section{Crystal structure description}

The structure of $\mathrm{Ce}_{3} \mathrm{Pt}_{4} \mathrm{Al}_{6}$ shows ordered occupation of all crystallographic sites. It is built of two identical atom layers of six-, five-, four- and three-membered rings at heights $y=1 / 4$ and $y=3 / 4$ (Fig. 1), related by inversion centers at $y=0$ and $y=1 / 2$. The Ce1 and $\mathrm{Ce} 2$ atoms are situated at the centers of hexagonal prisms with three and four additional atoms, respectively (Fig. 2a). The $\mathrm{Ce} 3$ atom is at the center of a pentagonal prism with two additional atoms.

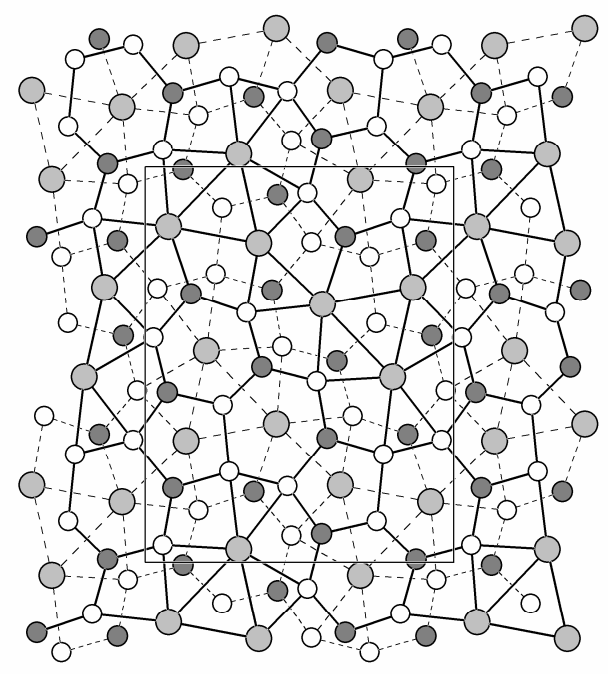

Fig. 1 Projection of the structure of $\mathrm{Ce}_{3} \mathrm{Pt}_{4} \mathrm{Al}_{6}$ on the XZ-plane. Light grey circles correspond to cerium atoms, dark grey circles to platinum atoms, and white circles to aluminum atoms. All atoms lie in the mirror planes at $y=1 / 4$ (dashed lines) and $y=3 / 4$ (solid lines).
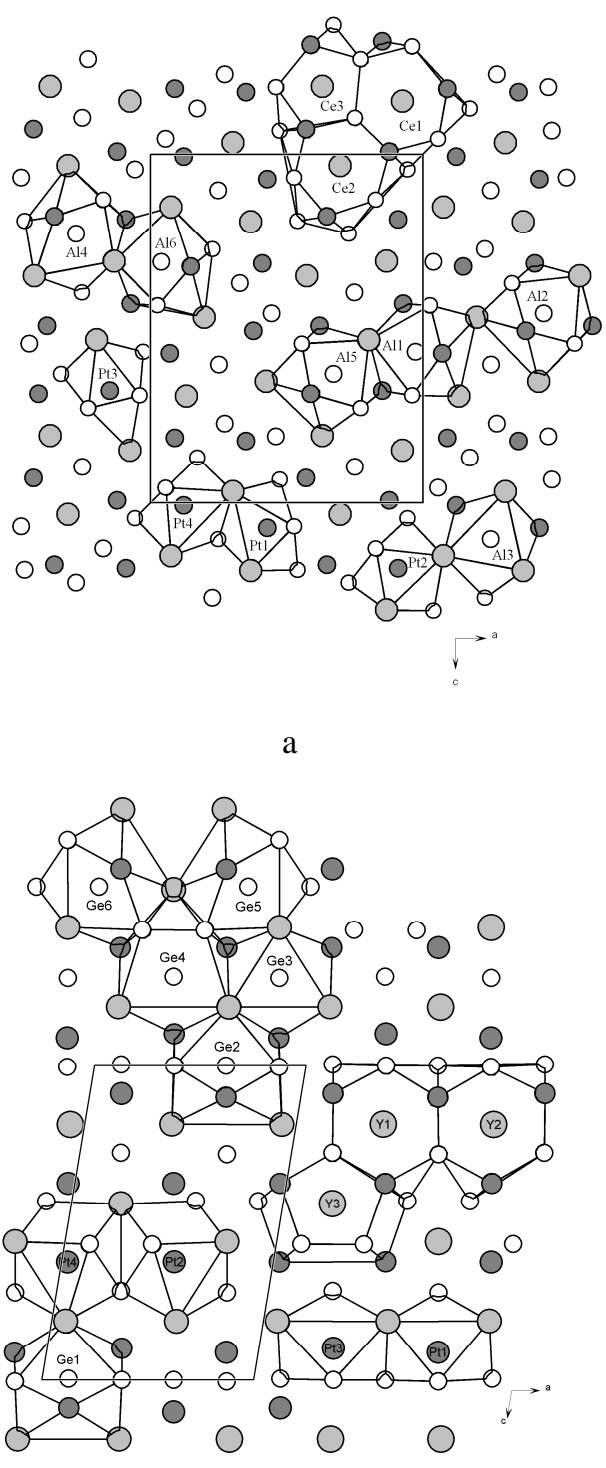

b

Fig. 2 Coordination polyhedra in the structures of $\mathrm{Ce}_{3} \mathrm{Pt}_{4} \mathrm{Al}_{6}$ (a) and $\mathrm{Y}_{3} \mathrm{Pt}_{4} \mathrm{Ge}_{6}(\mathrm{~b})$. 
Table 3 Interatomic distances in $\mathrm{Ce}_{3} \mathrm{Pt}_{4} \mathrm{Al}_{6}$.

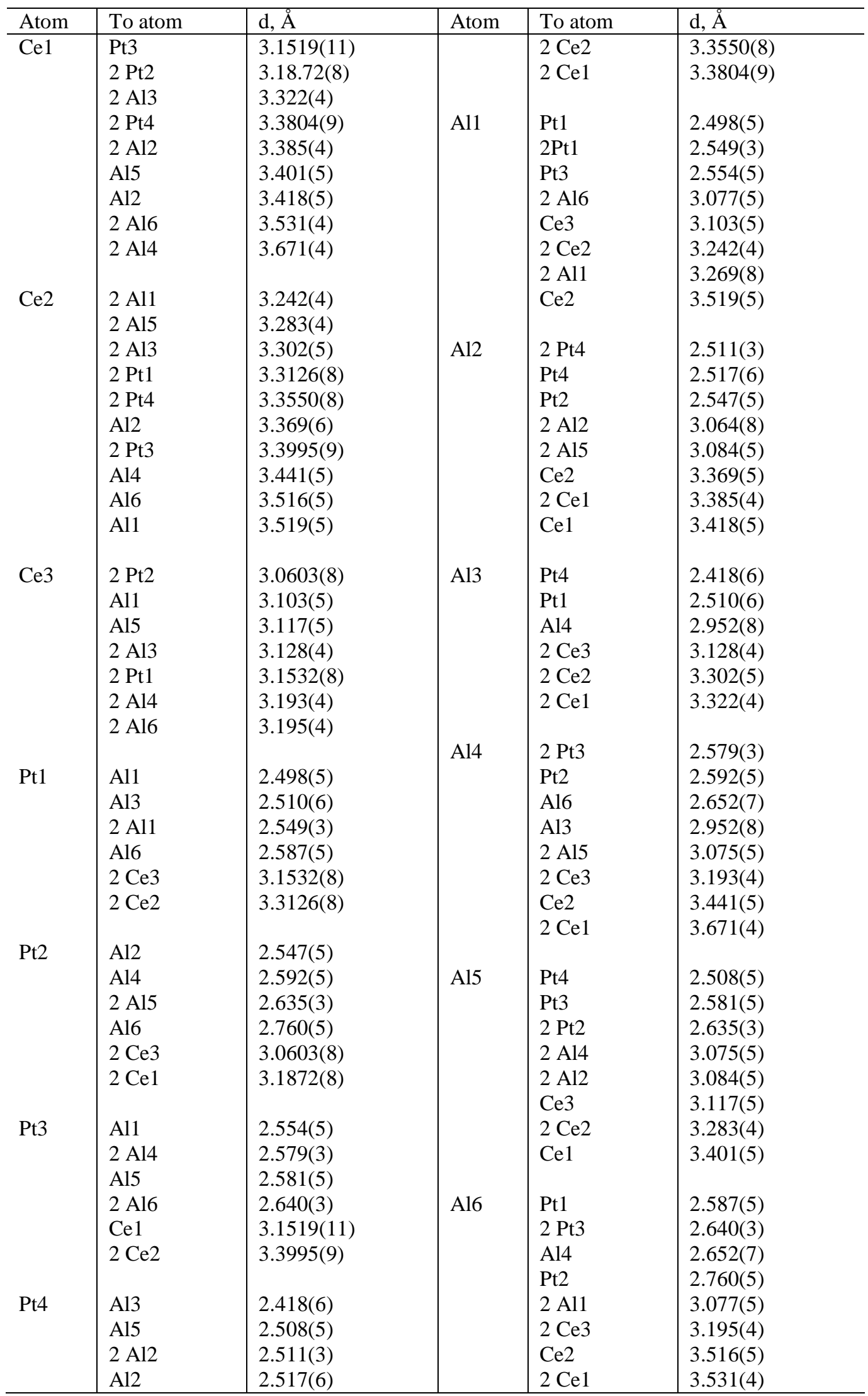


Table 4 Coordination polyhedra in the structures of $\mathrm{Ce}_{3} \mathrm{Pt}_{4} \mathrm{Al}_{6}$ and $\mathrm{Y}_{3} \mathrm{Pt}_{4} \mathrm{Ge}_{6}$ [4].

\begin{tabular}{|c|c|c|c|c|c|}
\hline $\begin{array}{l}\text { Atom and its } \\
\text { neighbors }\end{array}$ & $\mathrm{CN}$ & Polyhedron & $\begin{array}{l}\text { Atom and its } \\
\text { neighbors }\end{array}$ & $\mathrm{CN}$ & Polyhedron \\
\hline $\mathrm{Ce} 1\left[\mathrm{Pt}_{5} \mathrm{Al}_{10}\right]$ & 15 & $\begin{array}{l}\text { Hexagonal prism with } 3 \\
\text { additional atoms }\end{array}$ & $\mathrm{Y} 1\left[\mathrm{Pt}_{6} \mathrm{Ge}_{9}\right]$ & 15 & $\begin{array}{l}\text { Hexagonal prism with } 3 \\
\text { additional atoms }\end{array}$ \\
\hline $\mathrm{Ce} 2\left[\mathrm{Pt}_{6} \mathrm{Al}_{10}\right]$ & 16 & $\begin{array}{l}\text { Hexagonal prism with } 4 \\
\text { additional atoms }\end{array}$ & $\mathrm{Y} 2\left[\mathrm{Pt}_{6} \mathrm{Ge}_{9}\right]$ & 15 & $\begin{array}{l}\text { Hexagonal prism with } 3 \\
\text { additional atoms }\end{array}$ \\
\hline $\mathrm{Ce} 3\left[\mathrm{Pt}_{4} \mathrm{Al}_{8}\right]$ & 12 & $\begin{array}{l}\text { Pentagonal prism with } 2 \\
\text { additional atoms }\end{array}$ & $\mathrm{Y} 3\left[\mathrm{Pt}_{6} \mathrm{Ge}_{8}\right]$ & 14 & $\begin{array}{l}\text { Pentagonal prism with } \\
4 \text { additional atoms }\end{array}$ \\
\hline $\mathrm{Pt} 1\left[\mathrm{Ce}_{4} \mathrm{Al}_{5}\right]$ & 9 & $\begin{array}{l}\text { Trigonal prism with } 3 \\
\text { additional atoms }\end{array}$ & $\operatorname{Pt} 1\left[\mathrm{Y}_{4} \mathrm{Ge}_{5}\right]$ & 9 & $\begin{array}{l}\text { Trigonal prism with } 3 \\
\text { additional atoms }\end{array}$ \\
\hline $\mathrm{Pt} 2\left[\mathrm{Ce}_{4} \mathrm{Al}_{5}\right]$ & 9 & $\begin{array}{l}\text { Trigonal prism with } 3 \\
\text { additional atoms }\end{array}$ & $\mathrm{Pt} 2\left[\mathrm{Y}_{5} \mathrm{Ge}_{5}\right]$ & 10 & $\begin{array}{l}\text { Trigonal prism with } 4 \\
\text { additional atoms }\end{array}$ \\
\hline $\mathrm{Pt} 3\left[\mathrm{Ce}_{3} \mathrm{Al}_{6}\right]$ & 9 & $\begin{array}{l}\text { Trigonal prism with } 3 \\
\text { additional atoms }\end{array}$ & $\mathrm{Pt} 3\left[\mathrm{Y}_{4} \mathrm{Ge}_{5}\right]$ & 9 & $\begin{array}{l}\text { Trigonal prism with } 3 \\
\text { additional atoms }\end{array}$ \\
\hline $\mathrm{Pt} 4\left[\mathrm{Ce}_{4} \mathrm{Al}_{5}\right]$ & 9 & $\begin{array}{l}\text { Trigonal prism with } 3 \\
\text { additional atoms }\end{array}$ & $\mathrm{Pt} 4\left[\mathrm{Y}_{5} \mathrm{Ge}_{5}\right]$ & 10 & $\begin{array}{l}\text { Trigonal prism with } 4 \\
\text { additional atoms }\end{array}$ \\
\hline $\mathrm{Al} 1\left[\mathrm{Ce}_{4} \mathrm{Pt}_{4} \mathrm{Al}_{4}\right]$ & 12 & $\begin{array}{l}\text { Tetragonal prism with } 4 \\
\text { additional atoms }\end{array}$ & $\mathrm{Ge} 1\left[\mathrm{Y}_{4} \mathrm{Pt}_{4} \mathrm{Ge}_{4}\right]$ & 12 & $\begin{array}{l}\text { Tetragonal prism with } 4 \\
\text { additional atoms }\end{array}$ \\
\hline $\mathrm{Al} 2\left[\mathrm{Ce}_{4} \mathrm{Pt}_{4} \mathrm{Al}_{4}\right]$ & 12 & $\begin{array}{l}\text { Tetragonal prism with } 4 \\
\text { additional atoms }\end{array}$ & $\mathrm{Ge} 2\left[\mathrm{Y}_{4} \mathrm{Pt}_{4} \mathrm{Ge}_{4}\right]$ & 12 & $\begin{array}{l}\text { Tetragonal prism with } 4 \\
\text { additional atoms }\end{array}$ \\
\hline $\mathrm{Al} 3\left[\mathrm{Ce}_{6} \mathrm{Pt}_{2} \mathrm{Al}_{1}\right]$ & 9 & $\begin{array}{l}\text { Trigonal prism with } 3 \\
\text { additional atoms }\end{array}$ & $\mathrm{Ge} 3\left[\mathrm{Y}_{6} \mathrm{Pt}_{3}\right]$ & 9 & $\begin{array}{l}\text { Trigonal prism with } 3 \\
\text { additional atoms }\end{array}$ \\
\hline $\mathrm{Al} 4\left[\mathrm{Ce}_{5} \mathrm{Pt}_{3} \mathrm{Al}_{4}\right]$ & 12 & $\begin{array}{l}\text { Tetragonal prism with } 4 \\
\text { additional atoms }\end{array}$ & $\mathrm{Ge} 4\left[\mathrm{Y}_{5} \mathrm{Pt}_{3} \mathrm{Ge}_{4}\right]$ & 12 & $\begin{array}{l}\text { Tetragonal prism with } 4 \\
\text { additional atoms }\end{array}$ \\
\hline $\mathrm{Al} 15\left[\mathrm{Ce}_{4} \mathrm{Pt}_{4} \mathrm{Al}_{4}\right]$ & 12 & $\begin{array}{l}\text { Tetragonal prism with } 4 \\
\text { additional atoms }\end{array}$ & $\mathrm{Ge} 5\left[\mathrm{Y}_{4} \mathrm{Pt}_{3} \mathrm{Ge}_{5}\right]$ & 12 & $\begin{array}{l}\text { Tetragonal prism with } 4 \\
\text { additional atoms }\end{array}$ \\
\hline $\mathrm{Al} 6\left[\mathrm{Ce}_{5} \mathrm{Pt}_{4} \mathrm{Al}_{3}\right]$ & 12 & $\begin{array}{l}\text { Tetragonal prism with } 4 \\
\text { additional atoms }\end{array}$ & $\mathrm{Ge} 6\left[\mathrm{Y}_{4} \mathrm{Pt}_{3} \mathrm{Ge}_{5}\right]$ & 12 & $\begin{array}{l}\text { Tetragonal prism with } 4 \\
\text { additional atoms }\end{array}$ \\
\hline
\end{tabular}

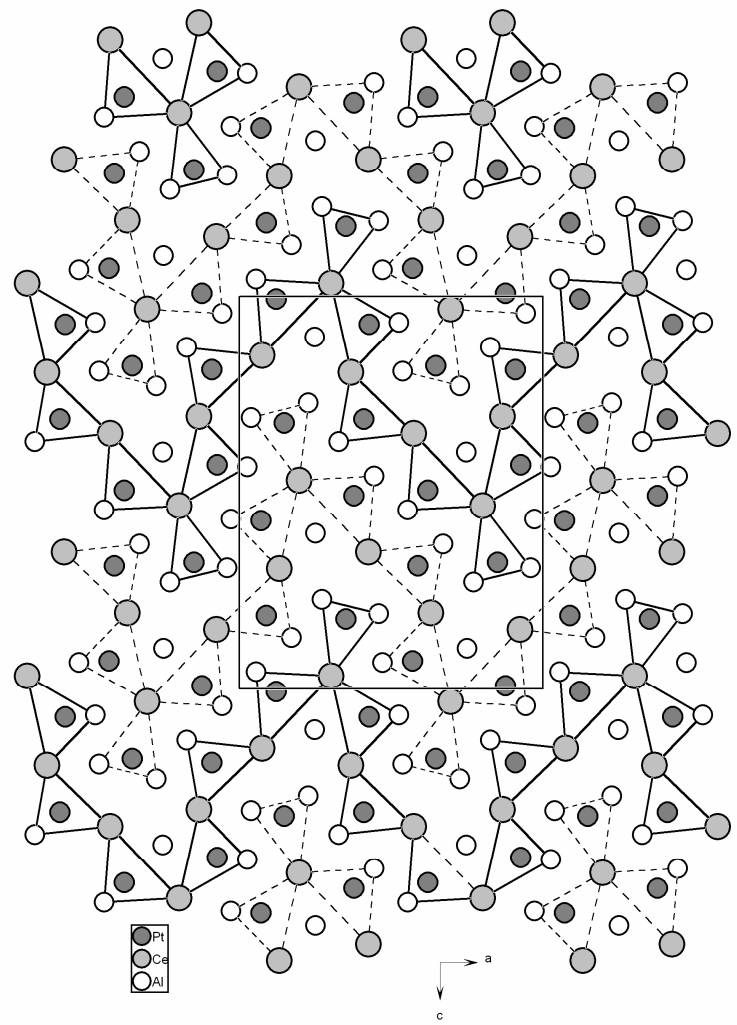

a

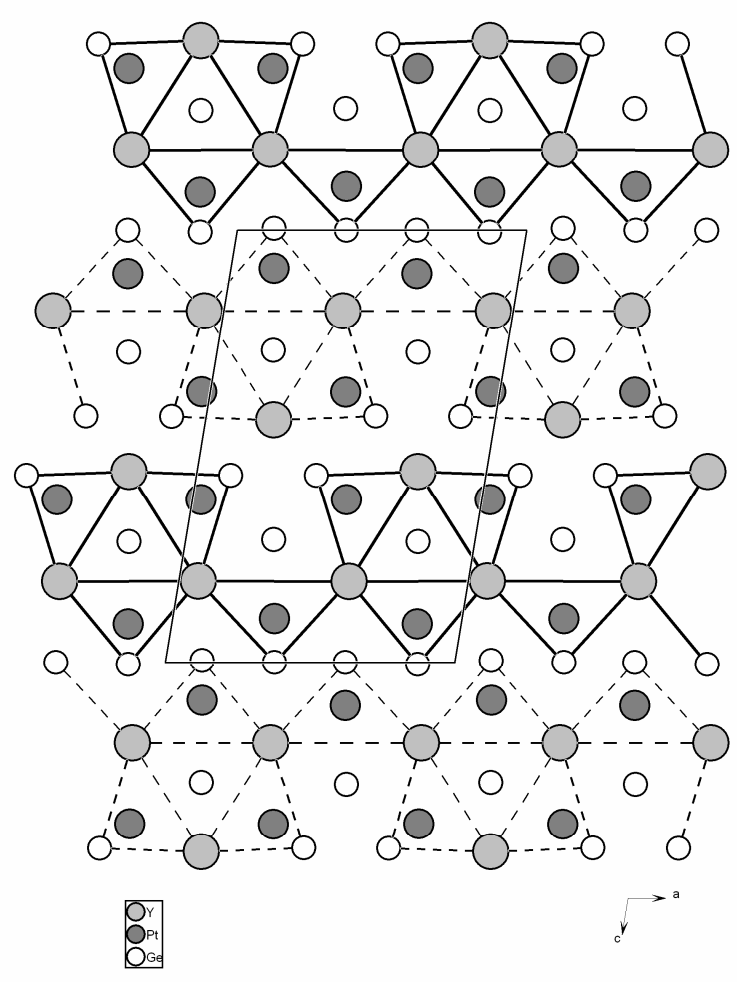

Fig. 3 The arrangement of Pt-centered trigonal prisms in the structures of $\mathrm{Ce}_{3} \mathrm{Pt}_{4} \mathrm{Al}_{6}$ (a) and $\mathrm{Y}_{3} \mathrm{Pt}_{4} \mathrm{Ge}_{6}(\mathrm{~b})$. 
All platinum atoms, as well as the $\mathrm{Al} 3$ atom, are coordinated by distorted trigonal prisms with three additional atoms capping the rectangular faces of the prisms. The remaining five crystallographically different aluminum atoms are located in significantly distorted four-capped tetragonal prisms.

Despite the fact that different sorts of atom form the coordination polyhedra in the structures of $\mathrm{Ce}_{3} \mathrm{Pt}_{4} \mathrm{Al}_{6}$ and $\mathrm{Y}_{3} \mathrm{Pt}_{4} \mathrm{Ge}_{6}$, the basic types of polyhedra of the corresponding elements are similar (Fig. 2), whilst the number of additional atoms is different for the polyhedra of two cerium (yttrium) and two platinum atoms (see Table 4). Though the types of coordination polyhedra in the structures of $\mathrm{Ce}_{3} \mathrm{Pt}_{4} \mathrm{Al}_{6}$ and $\mathrm{Y}_{3} \mathrm{Pt}_{4} \mathrm{Ge}_{6}$ are the same, the arrangement of the polyhedra in the structures is different. This can be demonstrated by representing the two structures as built of platinum centered trigonal prisms formed by cerium (yttrium) and aluminum (germanium) atoms (Fig. 3). These prisms form columns in the [010] direction by sharing triangular faces. The columns are condensed into groups by edge sharing of the constituent trigonal prisms.

\section{Acknowledgement}

This work was supported by the RFBR Project No 0803-00702_a. A.G. and P.R. are grateful to the OEAD for support within the framework of the AustrianRussian bilateral exchange program within Projects I.17/06 and RFBR 06-03-90579-BNTS_a.

\section{References}

[1] N.G. Bukhan'ko, A.I. Tursina, A.V. Gribanov, Y.D. Seropegin, O.I. Bodak, Proc. III Nat. Crystallochem. Conf., Chernogolovka, Russia, 2003, p. 101.

[2] E.V. Murashova, A.I. Tursina, N.G. Bukhan'ko, A.V. Gribanov, I.V. Chernyshev, Yu.D. Seropegin, J. Alloys Compd. 398 (2005) 100.

[3] A.V. Gribanov, O.L. Sologub, P.S. Salamakha, O.I. Bodak, Yu.D. Seropegin, V.K. Pecharsky, J. Alloys Compd. 179 (1992) L7.

[4] G. Venturini, B. Malaman, J. Less-Common Met. 167 (1990) 45.

[5] G.M. Sheldrick, SHELXS97 and SHELXL97. Univ. Göttingen, Germany, 1997.

[6] L.M. Gelato, E. Parthé, J. Appl. Crystallogr. 20 (1987) 139.

Proceeding of the IX International Conference on Crystal Chemistry of Intermetallic Compounds,

Lviv, September 20-24, 2005. 